\title{
PEMANFAATAN VCO MENGANDUNG KAROTENOID TOMAT DAN KARAGENAN DALAM PEMBUATAN LOTION
}

\author{
Riddel M. M. Y. Tumbelaka ${ }^{1)}$, Lidya I. Momuat ${ }^{1)}$, Audy D. Wuntu ${ }^{1)}$ \\ ${ }^{1)}$ Jurusan Kimia Fakultas Matematika dan Ilmu Pengetahuan Alam Unsrat Manado, 95115 \\ riddeltumbelaka@gmail.com
}

\begin{abstract}
Research has been conducted on the making of Lotion using VCO containing Tomato Carotenoids and Carrageenan with a mass concentration of 3\%. The stability of Lotion is determined by the stability of the emulsion in the Lotion preparation. The resulting Lotion was tested for quality according to SNI 16-4399-1996 standards, namely $\mathrm{pH}$, density, viscosity, and total microbial test. In addition, the resulting Lotion was tested for total carotenoids based on the reading results of $U V$-Vis Spectrophotometry. The results showed that the highest carotenoids in A1 samples were $129.99 \mathrm{mg} / \mathrm{L}$ and the lowest was in A6 samples $38.15 \mathrm{mg} / \mathrm{L}$. And the results of the Lotion quality test found in Lotion by using carrageenan were better than Lotion using cetyl alcohol.
\end{abstract}

Keywords: VCO, carrageenan, carotenoids, Lotion, SNI

\begin{abstract}
ABSTRAK
Telah dilakukan penelitian tentang Pembuatan Lotion menggunakan VCO mengandung Karotenoid Tomat dan Karagenan dengan konsentrasi massa 3\%. Kestabilan dari Lotion ditentukan dengan kestabilan emulsi dalam sediaan Lotion. Lotion yang dihasilkan diuji kualitas menurut standar SNI 16-4399-1996 yaitu uji pH, massa jenis, viskositas, dan total mikroba. Selain itu, Lotion yang dihasilkan diuji total karotenoid berdasarkan hasi pembacaan Spektrofotometri UVVis. Hasil penelitian menunjukkan bahwa yang memiliki Karotenoid tertinggi pada sampel A1 sebanyak 129,99 mg/L dan terendah pada sampel A6 38,15 mg/L. Dan hasil uji kualitas Lotion didapati Lotion dengan menggunakan karagenan lebih baik dibandingkan dengan Lotion menggunakan setil alkohol.
\end{abstract}

Kata kunci: VCO, karagenan, karotenoid, Lotion, SNI 


\section{PENDAHULUAN}

Tanaman Kelapa (Cocos nucifera) tersebar luas di Indonesia. Tahun 2011 luas area perkebunan kelapa Indonesia sebesar 3.752.000 Ha dengan jumlah produksi 3.204.050 ton (Direktorat Jendral Perkebunan Kementerian Pertanian, 2012). Kelapa merupakan salah satu dari tumbuhan yang paling berguna di dunia, khususnya di daerah tropis. Semua bagian kelapa baik itu dari sabut, tempurung, air, dan daging buah memiliki kegunaan. Untuk penggunaan di bidang kosmetik dan pengobatan yang paling banyak digunakan adalah bagian daging buahnya yang dapat diolah menjadi minyak kelapa. Minyak kelapa telah digunakan oleh masyarakat tropis selain untuk kegiatan memasak, namun digunakan juga sebagai pelembut kulit, memperkuat kesehatan rambut, dan menurut Sukartin (2005), dapat digunakan juga sebagai bahan baku shampoo, sabun, dan krim perawatan kulit.

\begin{tabular}{lll}
\multicolumn{1}{c}{ Virgin } & Coconut Oil & (VCO) \\
mempunyai & berbagai & keunggulan \\
dibandingkan & dengan minyak kelapa
\end{tabular}
biasa, maupun minyak nabati lainnya. VCO memliki kandungan asam lemak jenuh sebesar $92 \%$ yang berfungsi sebagai senyawa yang mencegah timbulnya ketengikan akibat oksidasi. Dalam hal inilah dapat dilihat keunggulan VCO dibandingkan minyak kelapa lainnya (Novarianto dan Tulalo, 2007), Struktur VCO yang kecil memudahkan kulit dan sabun untuk menyerapnya.

Ekstrak buah tomat mengandung pigmen karotenoid, terutama likopen dan $\beta$-karoten yang merupakan komponen utama penentu warna pada buah tomat masak (Langingi et al, 2012). Warna dan tekstur pada tomat segar merupakan atribut kualitas utama, yang secara langsung berhubungan dengan pemasaran. Karotenoid selain sebagai penentu warna, juga bermanfaat bagi kesehatan (Novita et al., 2015). Semakin tinggi kadar likopen pada buah tomat semakin tinggi pula aktivitas antioksidan (Maung et al., 2016).

Beragam produk minyak kelapa telah dihasilkan, di antaranya Virgin Coconut Oil mengandung karotenoid tomat (VCO+tomat) (Momuat et al., 2009). Senyawa karotenoid merupakan senyawa antioksidan larut minyak yang dapat berfungsi sebagai scavenger radikal bebas dalam tubuh dan kulit (Skibsted, 2012). Karenanya, VCO+tomat dapat dimanfaatkan baik dalam industri pangan (misal: minyak makan) maupun nonpangan (misal: kosmetik).

Lotion merupakan salah satu bahan turunan minyak yang biasa digunakan pada kulit. Lotion didefinisikan sebagai campuran dua fase yang tidak bercampur, distabilkan dengan sistem emulsi, dan berbentuk cairan yang dapat dituang jika ditempatkan pada suhu ruang (Schmitt, 1996). Pada penelitian ini, Lotion dibuat dengan memanfaatkan VCO+tomat sebagai minyak yang teremulsi dalam air. Untuk membuat Lotion dibutuhkan Emulsifying agent agar system emulsinya menjadi stabil.

Menurut Ramasari et al. (2012) Karagenan merupakan salah satu emulsifying agent alami yang diekstrak dari rumput laut. Struktur karagenan yang memiliki bagian polar dan non polar befungsi sebagai agen pengemulsi dalam pembuatan Lotion. Setil alkohol juga berperan sebagai agen pengemulsi yang memiliki gugus lipofil dan membantu menjaga tekstur dan daya sebar dari Lotion. 
Dalam penelitian ini produk Lotion dibuat dari olahan minyak kelapa yaitu VCO yang mengandung ekstak karatenoid tomat menggunakan emulsifying agent karagenan dan setil alkohol. Lotion yang dibuat selanjutnya diamati kualitasnya menurut SNI No. 164399-1996.

\section{METODE PENELITIAN}

\section{Alat dan Bahan Penelitian}

Bahan yang digunakan yaitu Daging kelapa, tomat, asam stearate, karagenan, paraffin cair, gliserin, trietanolamin (TEA), metil paraben, setil alkohol, Plate Count Agar (PCA), aquades, air.

Alat yang digunakan yaitu Seperangkat alat gelas, neraca analitik, blender, saringan 65 mesh, pemanas, wadah pemisah, alat sentrifugasi, batang pengaduk, stirrer, pipet tetes, $\mathrm{pH}$ meter, bola, cawan petri.

\section{Pembuatan santan}

Daging kelapa yang telah diparut dicampurkan dengan air panas bersuhu Pembuatan sediaan Lotion VCO+ekstrak Tomat

Tabel 1. Formulasi Lotion

\begin{tabular}{ccccccc}
\hline Bahan & \multicolumn{6}{c}{ Komposisi (\%massa) } \\
& $\mathbf{A 1}$ & $\mathbf{A 2}$ & $\mathbf{A 3}$ & $\mathbf{A 4}$ & $\mathbf{A 5}$ & $\mathbf{A 6}$ \\
\hline Fase Minyak & & & & & & \\
Asam Stearat & 2,5 & 2,5 & 2,5 & 2,5 & 2,5 & 2,5 \\
Parafin Cair & - & 3,5 & 7,0 & - & 7,0 & 3,5 \\
VCO+Ekstrak tomat & 7,0 & 3,5 & - & 7,0 & 3,5 & - \\
Fase Air & & & & & & \\
Karagenan & - & - & - & 3,0 & 3,0 & 3,0 \\
Setil Alkohol & 0,5 & 0,5 & 0,5 & - & - & - \\
Gliserin & 5,0 & 5,0 & 5,0 & 5,0 & 5,0 & 5,0 \\
TEA & 1,0 & 1,0 & 1,0 & 1,0 & 1,0 & 1,0 \\
Metil paraben & 0,1 & 0,1 & 0,1 & 0,1 & 0.1 & 0,1 \\
Aquades & 83,9 & 83,9 & 83,9 & 82,4 & 82,4 & 82,4 \\
Total & $\mathbf{1 0 0}$ & $\mathbf{1 0 0}$ & $\mathbf{1 0 0}$ & $\mathbf{1 0 0}$ & $\mathbf{1 0 0}$ & $\mathbf{1 0 0}$ \\
\hline
\end{tabular}

Formulasi Lotion pada penelitian ini tertera pada tabel 2. Bahan-bahan yang digunakan dalam pembuatan Lotion dipisahkan menjadi dua bagian yaitu $70^{\circ} \mathrm{C}$ dengan perbandingan 1:1 (1gram daging kelapa : $1 \mathrm{~mL}$ air) dalam baskom. Kemudian daging kelapa diperas dengan air dan disaring, santan yang diperoleh kemudian didiamkan selama 2 jam untuk memisahkan krim dan skim (Langingi et al., 2012).

\section{Pembuatan VCO mengandung Ekstrak Tomat}

Sebanyak $300 \mathrm{~mL}$ Ekstrak Tomat ditambahkan dengan $700 \mathrm{~mL}$ krim santan sehingga total campuran menjadi 1000 $\mathrm{mL}$ (Konsentrasi ekstrak tomat 30\%). Kemudian diaduk dan diamkan selama 18 jam. Dilakukan pemisahan antara air pada lapisan bawah dengan minyak dan blondo pada lapisan atas, dengan membuka keran pada bagian wadah. Disentrifugasi pada kecepatan 3000 rpm selama 15 menit untuk memisahkan minyak dari blondo. Blondo akan mengendap pada dasar tabung sedangkan minyak akan berada pada lapisan atas (Langingi et al., 2012). 
stearat, VCO dan parafin cair dimasukkan ke dalam gelas piala. Karagenan yang digunakan terlebih dahulu dilarutkan ke dalam air sebelum dicampurkan ke dalam fase air. Bahanbahan yang termasuk fase air adalah gliserin, TEA, larutan karagenan, setil alkohol.

Sediaan 1 dan 2 dipanaskan dan diaduk pada suhu $70-75^{\circ} \mathrm{C}$ secara terpisah hingga homogen (Sediaan 1 selama 10 menit, sediaan 2 selama 25 menit). Sediaan 1 dan 2 yang telah homogen tersebut dicampur dan diaduk dengan pengaduk. Proses pencampuran kedua sediaan yang berbeda tersebut dilakukan pada suhu $70^{\circ} \mathrm{C}$. Proses pengadukan dilakukan hingga campuran kedua sediaan homogen dan mencapai suhu $40^{\circ} \mathrm{C}$ (sediaan 3). Pengawet (metil paraben) dimasukkan ke dalam sediaan 3 pada suhu $35^{\circ} \mathrm{C}$ kemudian dilakukan pengadukan dengan stirrer selama kurang lebih satu menit (Anita, 2008).

\section{Uji Kualitas Lotion}

\section{Homogenitas}

Sampel diletakkan pada cawan petri kemudian dilihat homogenitasnya.

\section{Uji pH}

Pengukuran $\mathrm{pH}$ pada Lotion dilakukan menggunakan $\mathrm{pH}$ meter yang telah dikalibrasi dengan buffer equimolar pH 7 dan buffer kalium hidroksi ftalat $\mathrm{pH}$ 4. Elektroda dicelupkan ke dalam sediaan yang telah diencerkan dengan aquades, diamati $\mathrm{pH}$ yang dihasilkan (Ekowati \& Hanifah, 2016).

\section{Bobot Jenis}

Pengukuran ini dilakukan dengan menggunakan piknometer. Massa piknometer ditimbang terlebih dahulu dan dicatat (a). Kemudian sampel Lotion dimasukkan ke dalam piknometer sampai penuh lalu ditutup, ditimbang dan dicatat massanya (b). Bobot jenis Lotion ditentukan dengan rumus :

Bobot jenis

$=\frac{b-a}{\text { Volume Piknometer }(25 \mathrm{~mL})} \ldots \ldots \ldots$...Pers. 1

\section{Uji viskositas}

Pengukuran Viskositas dilakukan dengan metode bola jatuh. Bola yang digunakan ditimbang, kemudian sampel Lotion dimasukkan ke dalam gelas ukur $25 \mathrm{~mL}$ lalu masukkan bola ke dalam gelas ukur. Dihitung waktu yang dibutuhkan bola untuk mencapai tanda ter $5 \mathrm{~mL}$ dari $15 \mathrm{~mL}$. Dihitung juga panjang lintasan yang dilewati bola. Viskositas dihitung dengan menggunakan rumus Viskositas $=\frac{2 r^{2} g\left(\rho^{\prime}-\rho\right)}{9 v} \ldots$.......Pers. 2

Ket : $\quad r=$ Jari-jari bola $(\mathrm{m})$

$\mathrm{g}=$ Percepatan gravitasi $\left(\mathrm{m} / \mathrm{s}^{2}\right)$

$\mathrm{v}=\operatorname{Kecepatan}$ bola $(\mathrm{m} / \mathrm{s})$

$\rho^{\prime}=$ Massa jenis bola $\left(\mathrm{Kg} / \mathrm{m}^{3}\right)$

$\rho=$ Massa jenis fluida $\left(\mathrm{Kg} / \mathrm{m}^{3}\right)$

\section{Analisis total mikroba}

Pengukuran total mikroba berdasarkan SNI 19-2897-1992 adalah sebagai berikut, secara aseptis ditimbang Lotion sebanyak 1 gram dan dimasukkan ke dalam larutan pengencer sebanyak 1 $\mathrm{mL}$ kemudian dihomogenkan. Sebanyak $1 \mathrm{ml}$ sampel, diinokulasikan pada cawan petri steril. Media Plate Count Agar (PCA) yang steril pada suhu $45-55{ }^{\circ} \mathrm{C}$ dituangkan pada cawan petri sebanyak 20 $\mathrm{ml}$. Cawan petri digoyang dan dibiarkan memadat. Inkubasi dilakukan pada suhu kamar selama 24 jam. Jumlah koloni yang tumbuh dilaporkan sebagai total mikroba.

\section{Total Karotenoid}

Kandungan Karotenoid diukur dengan menggunakan metode Spektrofotometri. Sampel ditimbang sebanyak 2 gram dan dilarutkan dalam 10 
$\mathrm{mL}$ Aseton p.a sampai karotenoid larut kemudian disaring. Filtrat yang didapat ditempatkan dalam kuvet dan diukur total karotenoid dengan spektrofotometer pada panjang gelombang $480 \mathrm{~nm}, 645 \mathrm{~nm}$, dan $663 \mathrm{~nm}$. Setelah didapat nilai absorbansi kandungan karotenoid dihitung dengan rumus :

Total Karotenoid $(\mu \mathrm{mol} / \mathrm{L})=$ $\underline{(A 480+0,114 \times A 663-0,638 \times A 645) V \times 10^{3}}$

$112,5 \times W$

\section{HASIL DAN PEMBAHASAN}

Pembuatan VCO mengandung Ekstrak Tomat

Pembuatan Virgin Coconut Oil (VCO) dengan ekstrak tomat, didahului dengan pembuatan santan dari kelapa. Air yang digunakan dalam pembuatan santan terlebih dahulu dipanaskan hingga suhu $70^{\circ} \mathrm{C}$ agar supaya kelapa parut yang digunakan dalam pembuatan santan boleh terlarut dan minyak yang terdapat dalam kelapa dapat dikeluarkan. Dan santan yang diambil adalah hasil santan perasan pertama yang biasa dikenal dengan istilah kepala santan. Seperti yang diketahui hasil santan perasan pertama merupakan hasil santan yang mengandung lebih banyak minyak, yang berpengaruh pada hasil pembuatan VCO. Proses pendiaman selama 2 jam bertujuan untuk memisahkan krim dan skim. Krim santan terdapat pada lapisan atas dan skim terdapat pada lapisan bagian bawah. Untuk hasil santan yang dihasilkan dapat dilihat dalam Lampiran 4.

Kemudian Krim santan yang dihasilkan dicampur dengan ekstrak tomat dan digunakan perbandingan minyak dan ekstrak tomat adalah 7:3. Ekstra tomat dapat menjadi sumber karotenoid sehingga dapat dihasilkan VCO dengan kandungan karotenoid.
Didiamkan selama 18 jam, dengan tujuan terjadi pemisahan antara air dan minyak. Pemisahan terjadi karena adanya perbedaan kepolaran dan massa jenis (densitas) dari minyak dan air. Air yang memiliki densitas lebih tinggi dari minyak akan terletak pada bagian bawah, dan minyak yang memiliki densitas lebih rendah dari air akan terletak pada bagian atas. Proses pendiaman ini juga dilakukan dengan menutup bagian atas wadah tapi tidak terlalu rapat, untuk menghindari terbentuknya bakteri anaerob dalam VCO yang dihasilkan. Setelah dipisahkan dari air dan diambil minyaknya, disentrifugasi dengan kecepatan $3000 \mathrm{rpm}$ selama 15 menit untuk memisahkan minyak dari blondo. Minyak terdapat pada bagian atas tabung sedangkan blondo didasar tabung sentrifugasi.

\section{Pembuatan sediaan Lotion} VCO+ekstrak Tomat

Pembuatan Lotion VCO+ekstrak tomat, dilakukan dengan menggunakan emulsifying agent setil alkohol dan karagenan secara terpisah. Setiap alat gelas dan wadah disterilkan dengan pemanasan untuk menghindari adanya mikroba yang dapat menyebabkan pembusukan pada sediaan Lotion yang dihasilkan. Pembuatan Lotion dimulai dengan mencampurkan bahan sesuai fasenya yaitu fase air dan fase minyak pada suhu $70{ }^{\circ} \mathrm{C}$. Fase air pada sampel A4, A5 dan A6 menggunakan emulsifying agent karagenan. Larutan karagenan dibuat terlebih dahulu dengan cara ditimbang sebanyak 3 gram karagenan kemudian ditambahkan aquades yang dipanaskan dan didinginkan kembali sampai suhu $35{ }^{\circ} \mathrm{C}$ sebanyak 80,9 mL. Digunakannya aquades yang dipanaskan bertujuan untuk mematikan mikroba yang masih terdapat 
dalam aquades, sehingga mengurangi adanya mikroba dalam hasil Lotion yang didapatkan. Penambahan aquades dilakukan sedikit demi sedikit sambil larutan tetap diaduk, yang bertujuan untuk menghindari adanya penggumpalan pada larutan karagenan. Setelah larutan karagenan terbentuk, larutan dipanaskan pada suhu $70{ }^{\circ} \mathrm{C}$, dan dimasukkan bahan TEA dan gliserin sambil terus diaduk selama 25 menit. Pemanasan dan pengadukan berfungsi untuk memudahkan proses emulsifikasi. Kemudian fase minyak dipanaskan dengan suhu $70{ }^{\circ} \mathrm{C}$ sambil terus diaduk selama 10 menit. Perbedaan lamanya waktu pengadukan karena adanya perbedaan fase antara fase minyak dan fase air.

Setelah itu, fase air dan fase minyak dicampurkan dan diaduk selama 1 menit. Efektivitas proses emulsifikasi ditentukan oleh efisiensi pembentukan dan stabilisasi dari gumpalan antara air dan minyak yang terbentuk. Penambahan emulsifying agent bertujuan untuk menurunkan tegangan permukaan antara fase minyak dan fase air. Turunnya tegangan menyebabkan emulsifying agent membentuk lapisan yang mengelilingi fase minyak sehingga terbentuk tetesan dimana butiran minyak terdispersi ke dalam air. Setil alkohol dan asam stearat dalam sediaan Lotion berfungsi sebagai thicking agent atau agen pengental yang menjaga stabilitas dengan mengentalkan fase air. Penambahan TEA(Trietanolamin) yang bersifat basa berfungsi untuk menurunkan keasaman dari asam stearat yang dapat menyebabkan iritasi pada kulit. Sifat basa pada TEA menstabilkan $\mathrm{pH}$ dari asam stearat. Gliserin bersifat higroskopis yang berfungsi mencegah adanya proses penguapan air dari Lotion sehingga mencegah terbentuk kekentalan yang berlebih dan viskositasnya tidak semakin besar. Karagenan berperan sebagai bahan pengental sehingga penggunaan karagenan mempengaruhi penampakan skin Lotion. Karagenan termasuk salah satu polimer alami yang digunakan sebagai pengental dalam Lotion. Karagenan merupakan salah satu jenis hidrokoloid, yaitu suatu polimer larut dalam air yang mampu mengentalkan larutan. Parafin cair bersifat sebagai emollient (Rowe et al., 2009) sehingga dapat mencegah dehidrasi pada kulit dan juga dapat memberikan efek moisturizer (meningkatkan kandungan air). Efek moisturizer Lotion juga disebabkan adanya asam-asam lemak jenuh rantai sedang dan asam lemak tak jenuh pada VCO. Tidak semua asam lemak pada VCO yang dapat memberikan efek moisturizer. Hanya asam kaprat $\left(\mathrm{C}_{10}\right)$, asam laurat $\left(\mathrm{C}_{12}\right)$, asam miristat $\left(\mathrm{C}_{14}\right)$, asam oleat $\left(\mathrm{C}_{18-1}\right)$, asam linoleat $\left(\mathrm{C}_{18-2}\right)$, dan asam linolenat $\left(\mathrm{C}_{18-3}\right)$. Asam-asam lemak tersebut akan bertindak sebagai agen yang dapat mempertahankan kelembapan kulit dengan mengurangi penguapan air pada kulit. Metil paraben yang berfungsi sebagai pengawet antijamur digunakan pada produk Lotion untuk mencegah pertumbuhan jamur. Pengawet harus ditambahkan pada suhu yang tepat pada saat proses pembuatan skin Lotion, yaitu antara suhu $35^{\circ} \mathrm{C}$ $45^{\circ} \mathrm{C}$ agar tidak merusak bahan aktif yang terdapat dalam pengawet tersebut. Mikroba yang terdapat dalam suatu produk dapat menyebabkan emulsi tidak stabil.

\section{Uji Kualitas Lotion \\ Homogenitas}


Uji Homogenitas dilakukan untuk melihat kestabilan emulsi dari Lotion.

Tabel 2. Homogenitas Lotion
Adapun hasil yang didapatkan disajikan dalam Tabel 2.

\begin{tabular}{ccc}
\hline Sampel & Ulangan 1 & Ulangan 2 \\
\hline A1 & Homogen & Homogen \\
A2 & Homogen & Homogen \\
A3 & Homogen & Homogen \\
A4 & Homogen & Homogen \\
A5 & Homogen & Homogen \\
A6 & Homogen & Homogen \\
\hline
\end{tabular}

Suatu emulsi dapat dikatakan homogen apabila tidak terlihat adanya pemisahan antara komponen penyusun emulsi tersebut. Homogenitas sistem emulsi dipengaruhi oleh teknik atau cara pencampuran yang dilakukan serta alat yang digunakan pada proses pembuatan emulsi tersebut (Rieger 1994). Dari hasil uji Homogenitas didapatkan hasil bahwa stabilitas emulsi terbentuk dengan baik.

\section{Uji pH}

Uji $\mathrm{pH}$ dilakukan untuk mengukur tingkat keasaman sampel Lotion. Pengukuran $\mathrm{pH}$ dilakukan dengan menggunakan $\mathrm{pH}$ meter. Hasil yang didapat tersaji dalam Tabel 3.

Tabel 3. pH Lotion

\begin{tabular}{cccc}
\hline Sampel & Ulangan 1 & Ulangan 2 & Rata-rata \\
\hline A1 & 7,7 & 7,69 & 7,695 \\
A2 & 7,4 & 7,4 & 7,4 \\
A3 & 7,97 & 7,95 & 7,96 \\
A4 & 6,85 & 6,69 & 6,77 \\
A5 & 6,72 & 6,67 & 6,695 \\
A6 & 6,62 & 6,44 & 6,53 \\
\hline
\end{tabular}

Tabel 3 menyajikan hasil pengukuran terhadap nilai $\mathrm{pH}$ yaitu berikisar antara 7,4 -7,96 untuk Lotion yang menggunakan setil akohol (A1 - A3) dan antara 6,53-6,695 untuk Lotion yang menggunakan karagenan (A4 - A6). Nilai pH semua sampel Lotion memenuhi syarat SNI yaitu berkisar antara 4,5 - 8,0. Dari data yang didapatkan untuk Lotion yang menggunakan setil alkohol (A1-A3) hasil $\mathrm{pH}$ yang terbaik dimiliki oleh sampel A2 (Lotion VCO+paraffin cair) yang memiliki $\mathrm{pH}$ mendekati nilai 7 (netral). Jika Lotion yang dimiliki memiliki $\mathrm{pH}$ yang lebih rendah (suasana Tabel 4. Bobot Jenis Lotion asam) akan menyebabkan kulit kering dan iritasi, karena terjadinya kerusakan epidermis kulit. Penggunaan setil alkohol membuat $\mathrm{pH}$ Lotion menjadi lebih tinggi bila dibandingkan dengan menggunakan karagenan. Dapat dilihat bahwa hasil $\mathrm{pH}$ tertinggi dimiliki oleh Lotion sediaan A3 dan $\mathrm{pH}$ terendah dimiliki oleh Lotion sediaan A6.

\section{Bobot jenis Lotion}

pengukuran bobot jenis Lotion menggunakan alat piknometer. Hasil perhitungan massa jenis Lotion dapat dilihat dalam Tabel 4.

\begin{tabular}{cccc}
\hline Sampel & Ulangan 1 & Ulangan 2 & Rata-rata \\
\hline A1 & 0,964 & 0,974 & 0,969 \\
A2 & 0,872 & 0,975 & 0,923 \\
\hline
\end{tabular}




\begin{tabular}{lllc}
\hline A3 & 0,846 & 0,830 & 0,838 \\
A4 & 0,972 & 1,007 & 0.9895 \\
A5 & 1,007 & 1,001 & 1.004 \\
A6 & 0,976 & 0,983 & 0.9795 \\
\hline
\end{tabular}

Nilai bobot jenis Lotion yang menggunakan karagenan memiliki bobot jenis yang lebih kecil dibandingkan dengan Lotion yang menggunakan setil alkohol. Hal ini dikarenakan pada Lotion yang menggunakan karagenan, fungsi karagenan yaitu sebagai pengembang yang menyebabkan volume dari Lotion menjadi lebih besar sehingga nilai bobot jenis menjadi lebih rendah. Nilai bobot jenis yang dimiliki oleh tiap sampel Lotion berkisar antara 0,838 - 1.004 . Syarat bobot jenis Lotion menurut SNI adalah 0,95-1,05. Pada penelitian ini, Lotion A2 dan A3 yang menggunakan setil alohol tidak memenuhi SNI.

\section{Uji Viskositas}

Tabel 5. Perhitungan bola jatuh

\begin{tabular}{ccccc}
\hline Sampel & $\mathbf{t}_{\mathbf{1}}$ & $\mathbf{t}_{\mathbf{2}}$ & $\mathbf{t}_{\mathbf{3}}$ & $\mathbf{t}$ rata-rata \\
\hline A1 & 4,68 & 4,91 & 4,57 & 4,72 \\
A2 & 3,98 & 4,01 & 4,07 & 4,02 \\
A3 & 3,91 & 3,79 & 3,94 & 3,88 \\
A4 & 4,85 & 4,97 & 4,82 & 4,88 \\
A5 & 4,97 & 4,81 & 4,92 & 4,9 \\
A6 & 4,91 & 4,94 & 5 & 4,95 \\
\hline
\end{tabular}

Hasil pengujian rata-rata viskositas berdasarkan waktu pada tabel 5 dengan

menggunakan persamaan 2 tersaji dalam Tabel 6.

Tabel 6. Perhitungan Viskositas

\begin{tabular}{cc}
\hline Sampel & Viskositas (cP) \\
\hline A1 & 33795,13 \\
A2 & 29185,77 \\
A3 & 29003,37 \\
A4 & 34720,93 \\
A5 & 34702,91 \\
A6 & 35368,66 \\
\hline
\end{tabular}

Hasil viskositas yang didapat cenderung sama, dan memenuhi syarat SNI.
Pengukuran Viskositas Lotion dilakukan dengan metode bola jatuh dan didapati nilai keofisien viskositas yang menyatakan tingkat kekentalan atau viskositas sampel Lotion. Untuk menentukan nilai viskositas, terlebih dahulu ditentukan waktu jatuh bola dalam fluida (sampel). Adapun hasil perhitungan waktu jatuh bola untuk masing-masing sampel disajikan dalam Tabel 5. Perhitungan waktu jatuh bola digunakan untuk menentukan kecepatan gerak bola dalam tabung reaksi dari skalah $15 \mathrm{~mL}$ ke $5 \mathrm{~mL}$. Jarak antara skala $15 \mathrm{~mL}$ dan $5 \mathrm{~mL}$ pada tabung reaksi 25 $\mathrm{mL}$ adalah $0,042 \mathrm{~m}$ 
memiliki nilai vikositas yang cenderung lebih rendah daripada sampel Lotion yang menggunakan karagenan (A4-A6). Hal ini disebabkan oleh karagenan bertindak sebagai agen pengental pada Lotion yang menyebabkan viskositas atau kekentalannya bertambah. Berbeda dengan penggunaan setil alkohol yang hanya berperan sebagai surfaktan pada sintesis Lotion. Dapat dilihat bahwa nilai visositas juga berpengaruh pada massa jenis. Semakin tinggi viskositas semakin besar pula massa jenis Lotion yang dihasilkan.

\section{Analisa total mikroba}

Tabel 7. Analisa Total mikorba

\begin{tabular}{cccc}
\hline Sampel & Ulangan 1 & Ulangan 2 & $\begin{array}{c}\text { Total } \\
\text { koloni/gram }\end{array}$ \\
\hline A1 & 40 & 47 & 43,5 \\
A2 & 15 & 24 & 19,5 \\
A3 & 11 & 19 & 15 \\
A4 & 4 & 2 & 3 \\
A5 & 14 & 12 & 13 \\
\hline \multirow{2}{*}{ Sampel } & \multicolumn{2}{c}{ Absorbansi } & Total Karotenoid \\
& $\mathbf{4 8 0} \mathbf{~ n m ~} \mathbf{6 6 3} \mathbf{~ n m ~} \mathbf{6 4 5} \mathbf{~ n m}$ & $(\boldsymbol{\mu m o l} / \mathbf{L})$
\end{tabular}

\begin{tabular}{llll} 
A6 & 3 & 2 & 2,5 \\
\hline
\end{tabular}

Uji total mikroba adalah uji untuk mengetahui ada atau tidak adanya mikroba dalam skin Lotion yang dihasilkan. Uji ini merupakan salah satu uji yang penting karena kontaminasi mikroba dapat menyebabkan pemisahan fase, penyusutan berat produk, dan bau yang tidak sedap. Skin Lotion merupakan suatu produk yang memiliki jangka waktu pemakaian yang cukup lama, sehingga adanya mikroba dalam skin Lotion dapat menjadi masalah terhadap daya awet skin Lotion. Pemakaian pengawet sangat dibutuhkan dalam formulasi skin Lotion. Kontaminasi mikroorganisme walaupun bukan termasuk mikroorganisme pathogenik tidak diinginkan dalam kosmetika karena dapat menyebabkan terjadinya deteriorasi atau penurunan mutu pada kualitas produk seiring waktu pemakaian dan akan menyebabkan iritasi kulit (Mitsui 1997).

Uji total mikroba pada skin Lotion menunjukkan bahwa tidak terdapat mikroba pada skin Lotion yang dihasilkan. Penggunaan bahan pengawet yaitu metil paraben pada formulasi terbukti efektif untuk mencegah tumbuhnya mikroba yang dapat merusak produk skin Lotion.

\section{Total Karotenoid}

Tabel 8. Total Karotenoid 


\begin{tabular}{ccccc}
$\mathbf{A 1}$ & 0,202 & 0,182 & 0,181 & 4,77 \\
$\mathbf{A 2}$ & 0,140 & 0,126 & 0,127 & 3,26 \\
$\mathbf{A 3}$ & 0,079 & 0,067 & 0,068 & 1,92 \\
$\mathbf{A 4}$ & 0,179 & 0,172 & 0,173 & 3,92 \\
$\mathbf{A 5}$ & 0,152 & 0,134 & 0,135 & 3,61 \\
$\mathbf{A 6}$ & 0,060 & 0,052 & 0,054 & 1,40 \\
VCO & 1,344 & 0,080 & 0,080 & 57,87 \\
\hline
\end{tabular}

Tabel 8 Menunjukan total karotenoid dari VCO dan sampel Lotion. Dari tabel dapat dilihat hasil total karotenoid tertinggi pada sampel Lotion A1 dan terendah pada sampel Lotion A6. Untuk sampel Lotion menggunakan setil alkohol (A1, A2, dan A3) didapati total karotenoid lebih besar dibandingkan A2 dan A3 sedangkan untuk Lotion menggunakan karagenan (A4, A5, dan A6) Lotion A4 didapati total karotenoid lebih besar dibandingkan A5 dan A6 . Hal ini dikarenakan pada Lotion A1 menggunakan VCO lebih banyak dibandingkan dengan Lotion A2 dan A3. VCO yang digunakan dalam pembuatan Lotion merupakan penyumbang karotenoid dalam sampel karena dalam VCO terlarut karotenoid yang berasal dari tomat. Hal ini dilihat dari hasil uji total karotenoid pada sampel VCO.

\section{KESIMPULAN}

Berdasarkan penelitian yang telah dilakukan dapat disimpulkan bahwa :

a. VCO mengandung ekstrak tomat dapat dibuat Lotion dengan karagenan sebagai emulsifying agent.

b. Untuk Lotion menggunakan emulsifying agent Karagenan (A4,A5 dan A6) memenuhi SNI sedangkan untuk emulsifying agent Setil Alkohol (A1, A2 dan A3) hampir keseluruhan memenuhi SNI. Lotion menggunakan Setil Alkohol tidak memenuhi syarat bobot jenis untuk sampel A2 dan A3.

\section{DAFTAR PUSTAKA}

[SNI] Standar Nasional Indonesia 164399. 1996. Sediaan Tabir Surya. Badan Standarisasi Nasional, Jakarta.

[SNI] Standar Nasional Indonesia 192897. 1992. Penentuan Total Mikroba. Badan Standarisasi Nasional, Jakarta.

Andayani, R., Maimunah., \& Lisawati, Y. 2008. Penentuan Aktivitas Antioksidan, Kadar Fenolat Total dan Likopen pada Buah Tomat (Solanum lycopersicum L). Jurnal Sains dan Teknologi Farmasi. 13(1) : 31-37.

Anggadiredja J, T, Zatnika A, Purwoto H, Istini S. 2006. Rumput Laut. Jakarta: Penebar Swadaya

Angka S, L, \& Suhartono M, T. 2000. Bioteknologi Hasil Laut. Bogor: Pusat Kajian Pesisir dan Lautan, Institut Pertanian Bogor.

Anita, S. B. 2008. Aplikasi Karagenan dalam Pembuatan Skin Lotion [skripsi]. FPIK IPB, Bogor.

Ansel, H. C. 1989. Pengantar Bentuk Sediaan Farmasi. UI-Press, Jakarta. 
Badan Pusat Statistik. 2011. Data Produksi Tomat. Diunduh dari http://www.bps.go.id/

Davis, K. J., \& Goldberg A. I. 1987. Protein damaged by Oxygen radicals are Rapidly Degraded to Extracts of Red Blood Cells. Journal of Biology Chemistry. 2(62) : 8227-8234

Di Mascio, P., Kaiser, S., \& Sies H. 1989. Lycopene as the Most Efficient Biological Carotenoid Singlet Oxygen Quencher. Archives of Biochemistry and Biophysics.

Dreher T. M., Glass J., Connor A. J. O., \& Steven G. W. 1997. Effect of Rheology on Coalescence Rates and Emulsion Stability. AIChE Journal Vol 45 No 6.

Dorobantu L. S., Yeung A. K. C., Foght J. M, Gray M. R. Stabilization of Oil Water Emulsion by Hydrophobic Bacteria. Journal of Microbiology Vol 70 No 10.

Ekowati, D. \& Hanifah, I. R. 2016.

Potensi Tongkol Jagung (Zea Mays L.) sebagai Sunscreen dalam Sediaan Hand Body Lotion. Jurnal Ilmiah Manuntung. 2(2) : 198-207.

Fardiaz D. 1989. Hidrokoloid. Laboratorium Kimia dan Biokimia Pangan. Bogor: Pusat Antar Universitas Pangan dan Gizi, Institut Pertanian Bogor.

Glicksman M. 1983. Food Hydrocolloids. Florida: CRC Press.

Guibet M., Colin S., Barbeyron T., \& Genicot S. 2006. Degradation of $\lambda$-Carrageenan by Pseudoalteromonas carrageenovora $\lambda$-Carrageenase: a New Family of Glycoside
Hydrolases Unrelated to $\kappa$-and $1-$ Carrageenases. Journal of Biochemistry 10: 105-115

Halliwel, B. \& Gutteridge, J. M. C. 2001. Free Radicals in Biology and Medicine. Oxford University Press, London.

Jitputti, J., Kitiyanan, B., Rangsunvigit., Bunyakiat, K., Attanatho, L., \& Jenvanitpanjakul, P. 2006. Transesterification of Crude Palm Kernel Oil and Crude Coconut Oil by Different Solid Catalysts. Chemical Engineering Journal. 116(1) : 61-66.

Langingi, R., Momuat, L. I., \& Kumaunang, M. G. 2012. Pembuatan Sabun Mandi Padat dari VCO yang Mengandung Karatenoid Wortel. Jurnal MIPA UNSRAT Online. 1 (1) : 20-23.

Lu, Y., et al. 1995. A New Carotenoid, Peroxide Oxidation Products from Lycopene. Journal of Biochemistry. 5(9) : 2153-2155.

Min, D. B. \& Boff J. M. 2002. Chemistry and Reaction of Singlet Oxygen in Foods. Food Science and Food Safety. 1(1): 58-72.

Mansor, T. S. T., Man, C. Y. B., Shuhaimi, M., Afiq A. M. J., \& Nurul F. K. M. 2012. Physicochemical Properties of Virgin Coconut Oil Extracted from Different Processing Methods. International Food Research Journal. 19(3) : 837845

Maong, R., Rorong, J. A. \& Fatimah, F. 2016. Aktivitas Ekstrak Buah Tomat (Lycopersicum esculentum Mill) sebagai Penstabil Oksigen Singlet dalam 
Reaksi Fotooksidasi Asam Linoleat . Jurnal Mipa Unsrat Online. 5 (1) : 60-64.

Mitsui. 1997. New Cosmetic Science. NewYork: Elsevier.

Momuat, L. I., Sangi, M. S., \& Purwati N. P. 2011. Pengaruh VCO Mengandung Ekstrak Wortel terhadap Peroksidasi Lipid Plasma. Jurnal Ilmiah Sains. 11(2) : 296-301.

Nevin, K. G. \& Rajamohan, T. 2004. Beneficial effect of Virgin Coconut Oil on Lipid Parameters and in Vitro LDL Oxidation.

Clinical Biochemistry. 30(1) : 830-835.

Novarianto, H. \& Tulalo, M. 2007. Kandungan Asam Laurat pada Berbagai Varietas Kelapa sebagai Bahan Baku VCO. Jurnal Littri. 13(1) : 28-33.

Novita, M., Satriana. \& Hasmarita, E. 2015. Kandungan Likopen dan Karotenoid Buah Tomat (Lycopersicum Pyriforme) pada Berbagai Tingkat Kematangan : Pengaruh Pelapisan Dengan Kitosan dan Penyimpanan. Jurnal Teknologi dan Industri Pertanian Indonesia. 7(1) : 3539.

Polo KFD. 1998. A Short Textbook of Cosmeticology. Ed ke-1. Jerman: Verlag fur Chemische Industrie

Ramasari, E. L., Ma'ruf, W. F., \& Riyadi, P. H. 2012. Aplikasi Karagenan sebagai Emulsifier di dalam pembuatan Sosis Ikan Tenggiri (Scomberomorus guttatus) pada Penyimpanan Suhu Ruang. Jurnal Perikanan. 1(2) : 1-8.
Rieger M. 1994. Emulsi. Di dalam : Lachman et al. 1994. Teori dan Praktek Farmasi Industri. Ed ke2. Suyatmi S, penerjemah. Jakarta: UI Press. Terjemahan dari Theory and Pharmacy Practical Industry. Ed ke-2.

Rieger M. 2000. Harry's Cosmeticology. Ed ke-8. New York: Chemical Publishing Co Inc.

Schmitt, W. H. \& Williams, D. F. 1996. Chemistry and Technology of Cosmetics and Toiletries Industry. Blackie Academy and Profesional, London.

Shahidi, F. 1997. Natural Antioxidant. Department of Biochemistry Memorial University of Newfounland St. Jhon's, Newfoundland, AOCS Press. Canada.

Soehardi, S. 2004. Memelihara Kesehatan Jasmani Melalui Makanan. ITB, Bandung.

Surtinah. 2007. Kajian Tentang Hubungan Pertumbuhan Vegetatif Dengan Produksi Tanaman Tomat (Lycopersicum esculentum, Mill) PS. Agronomi, Staf Pengajar Fakultas Pertanian Universitas Lancang Kuning, Vol. 4 No 1.

Suryani A., Sailah I., \& Hambali E. 2000. Teknologi Emulsi. IPB, Bogor.

Tirono, M. \& Sabit M. 2011. Efek Suhu pada Proses Pengarangan terhadap Nilai Kalor Arang Tempurung Kelapa (Coconut Shell Charcoal). Jurnal Neutrino. 3(2) : 143-152.

Tugiyono, H. 2006. Bertanam Tomat. Penebar Swadaya, Jakarta. 